\title{
The Value of Character Education in Engklek Games at Primary School
}

\author{
Yuli Ana Sitio ${ }^{1 *}$, Budi Usodo ${ }^{2}$, Riyadi ${ }^{3}$ \\ ${ }^{1,2,3}$ Faculty of Teacher Training and Education, Universitas Sebelas Maret, Indonesia \\ *Corresponding author. Email: sitioyuliana@gmail.com
}

\begin{abstract}
Rapid technological advances have an impact on students. One of the negative impacts is the occurrence of moral degradation in the child's environment. Moral degradation in children is shown in data from the KPAI (Indonesian Child Protection Commission) taken fromhttps://www.kpai.go.id/as of 2019 which shows cases of bullying in schools, murders, and cases of suicide. With a high level of moral degradation in students, it is very necessary to instill the value of character education from an early age because it can lead children to maturity in processing emotions. This study aims to describe the character education values contained in the engklek games. This research is a type of qualitative research. The data sources of this research are resource persons and children's activities. The data collection technique is done by interviewing, Observations, and documents Data analysis uses the interactive model of analysis by Miles and Huberman with the stages of data collection, data reduction, data presentation, and verification. These values can be used by children as a means to instill character education in the child's environment and interpret the meaning contained in the engklek game. The results of this study are in the form of character education values contained in the engklek game at primary school including nationalism, independence, cooperation, and, integrity.
\end{abstract}

\section{Keywords: Value of Character Education, Engklek games, Primary School}

\section{INTRODUCTION}

Globalization has brought various challenges to the pursuit of national identity. To address these challenges, one must scientifically define the related theories [1]. Nowadays, students play more with modern technology, such as cell phones, gadgets, computers, and laptops which result in forgetting the values contained in traditional games [2]. Traditional games are rarely played by students even though traditional games are no less fun when competing with games that use advanced technology. Rapid technological advances have an impact on students. One of the negative impacts is the occurrence of moral degradation in the child's environment. Moral degradation in children can be seen from the KPAI (Indonesian Child Protection Commission) data are taken from http: //www.kpai.go. en / as the year 2019 which shows cases of bullying in schools, murders, and suicides. With a high level of moral degradation in children, it is very necessary to instill the value of character education from an early age because it can lead children to maturity in processing emotions [3]. One important thing in the curriculum is how to build a character consisting of attitudes, skills, and knowledge [4]. Therefore, the curriculum and learning process needs to be redirected and aligned with the development goals of the nation's character to realize the goal [5].

Values education is educating students to know what is good, love what is good, and do what is good. In short, values education is ultimately about improving behavior or changing behavior for the better. Since this behavior is a translation of thoughts and feelings about valuable values, good behavior is autonomous and rational-altruistic. Therefore the basic principles of civilization are neglected. It is imperative to create an environment for students to benefit from revealing for themselves what desired and undesirable behaviors, and what values are necessary for the long-term well-being of themselves and others. On the other hand, if the values educator acts like the preacher and practices direct instruction instead, value education will then become value indoctrination [6]. When a person is considered to have good character as is usually used, that person also has several other qualities such as 
trustworthiness, integrity, passion, dependability [7]. Moreover, it causes all changes in every aspect of life, especially the social conditions of the community, for example, a lack of tolerance and care for each other [8].

Strengthening character education is a movement that is the responsibility of educational units to improve the character of students through alignment of hearts, feelings, thoughts, and sports with interaction and cooperation between educational units, families and communities as part of the National Revolution Movement [9]. Value education contains several meanings and can occur anywhere. Even so, schools are also places where educational values make sense [10]. School is one of the places for students to get character education. The values and goals of the school are held together through mentoring and cooperation between school communities who jointly plan for the future, and jointly solve the problems at hand [11]. Local culture is very important for character education in Indonesia which continues to explore the local cultural values that are still stored [12]. By applying the values of character education, the school culture will produce a good performance and have an impact on the competence of quality graduates [13].

One of the implementations of character education in elementary schools is to integrate learning through traditional games. Traditional games are a form of children's play that circulates orally among certain collectives, are traditional and are inherited from hereditary, and have a lot of variances. The engklek game is a traditional game in Indonesia that has existed since the Dutch colonial era. Some people argue that this game originated in England. This game is also known as stone-throwing or gacok [14]. By using traditional games in mathematics learning can provide good benefits for children's development both physically, emotionally, and cognitively [15]. This traditional game can also train students' character be it honesty, queuing for games, togetherness, and sportsmanship. In the game, it also trains the fine motor and gross motor skills of students who play it in the form of balance and others. cooperation, cohesiveness, and togetherness [16]. The results of this study aim to describe the character education values contained in the game. and increase the sense of cooperation, cohesiveness, and togetherness [17].

\section{METHOD}

The research was a qualitative descriptive study in which the participants of the research were 74-second grade students of the 2019/2020 school year MIN 9 Sragen, Indonesia. The data sources of this research are resource persons and children's activities. The data collection technique is done by interviewing, Observations, and documents Data analysis uses the interactive model of analysis by Miles and Huberman with the stages of data collection), data reduction, data presentation, and concluding (verification). The validity of the data used was the triangulation of techniques and resources by analyzing values that can be used by children as a means to instill character education value in the child's environment and interpret the meaning contained in the engklek games. Then, the results linked with the results of interviews, observations, and documents through Milles \& Huberman's interactive analysis. The interactive analysis consists of four stages, namely data collection, data reduction, data presentation, and drawing conclusions or verification. Triangulation is carried out by bringing together several indicators that are interconnected indicators [18]

\section{RESULTS AND DISCUSSION}

This study describes the value of character education, rules, and how to play engklek in mathematics learning in the second grade of elementary school. The results and discussion are as follows:

\subsection{Description and Indicator Character Value}

To be able to determine the value of character education in students, it is necessary to have clear descriptions and indicators to make it easier for teachers to determine the value of character education that is visible. The description and character indicators are as follows: 
Table 1. Description and Indicator Character Value

\begin{tabular}{|c|c|c|c|}
\hline No & Character & Description & Indicator \\
\hline & Religious & $\begin{array}{l}\text { Attitude and carry out his religious } \\
\text { teachings }\end{array}$ & Diligently do worship and pray \\
\hline 2 & Tolerant & $\begin{array}{l}\text { Attitudes and actions to respect } \\
\text { differences }\end{array}$ & $\begin{array}{l}\text { Can accept the existence of different friends } \\
\text { Can respect different opinions and actions of friends }\end{array}$ \\
\hline 3 & Discipline & $\begin{array}{l}\text { Actions demonstrate orderly } \\
\text { behavior and obey the rules }\end{array}$ & $\begin{array}{l}\text { Always follow lessons and activities orderly } \\
\text { Always obey the school rules and regulations }\end{array}$ \\
\hline 4 & Hard work & $\begin{array}{l}\text { Behavior that shows a genuine } \\
\text { effort to overcome obstacles and } \\
\text { tasks }\end{array}$ & $\begin{array}{l}\text { Always mean to do your job } \\
\text { Always try to overcome learning barriers }\end{array}$ \\
\hline 5 & Creative & $\begin{array}{l}\text { Think and do something to come } \\
\text { up with a new way }\end{array}$ & Always finding new ways to complete assigned tasks \\
\hline 6 & To be responsible & $\begin{array}{l}\text { Readiness and behavior to carry out } \\
\text { duties and obligations }\end{array}$ & Always committed to carrying out duties \\
\hline 7 & Love peace & $\begin{array}{l}\text { Attitudes, words, and actions cause } \\
\text { other people to feel happy and } \\
\text { secure in their presence }\end{array}$ & $\begin{array}{l}\text { Always say softly } \\
\text { Always avoid hostility } \\
\text { Provide security to others }\end{array}$ \\
\hline 8 & Honest & $\begin{array}{l}\text { Behavior is based on efforts to } \\
\text { make himself a person who is } \\
\text { always trusted in words and actions }\end{array}$ & $\begin{array}{l}\text { Always tell the truth and what it is } \\
\text { Act according to the rules } \\
\text {. Trustworthy and doesn't like to lie }\end{array}$ \\
\hline 9 & Independent & $\begin{array}{l}\text { Attitudes and behaviors that are } \\
\text { not easy to depend on other } \\
\text { people to complete tasks. }\end{array}$ & Always try to do the assigned task yourself \\
\hline 10 & Communicative & $\begin{array}{l}\text { Actions that show a sense of } \\
\text { pleasure in talking, socializing, and } \\
\text { collaborating with others }\end{array}$ & $\begin{array}{l}\text { Always be friendly in speaking } \\
\text { Always able to hang out with various circles and have } \\
\text { many friends } \\
\text { Always able to maintain a harmonious relationship } \\
\text { Always be friendly in spea } \\
\text { Always able to hang out with various circles and have } \\
\text { many } \\
\text { Always able to maintain a harmonious relationship }\end{array}$ \\
\hline 11 & Love the homeland & $\begin{array}{l}\text { The way of thinking, behaving, and } \\
\text { acting shows high respect for the } \\
\text { nation's culture }\end{array}$ & $\begin{array}{l}\text { Always love Indonesian culture } \\
\text { Always loyal to the homeland } \\
\text { Care for the environment }\end{array}$ \\
\hline
\end{tabular}

Based on the table above, shows the value of character education along with the descriptions and indicators used by the teacher as a guideline for assessing student attitude journals during learning, so that it can make it easier for teachers to determine the aspects that will be assessed and appear in students during learning. Based on an interview with second Class teacher, he said that the school already has an 
attitude journal which is used as a guide for observing student attitudes and activities which will later be included in the report card.

The same thing was also obtained based on the results of interviews with several students who said that students prefer to study at school with good friends. They say those annoying friends should get bad grades and get reprimanded by the teacher. From the interview, it can be seen that an assessment of character education is needed both in learning and outside learning in the school environment to produce a noble generation of people. Students also feel comfortable studying and have friends with good character. Meanwhile, based on the results of the document analysis, the teacher paid less attention to existing journals. These documents have not been used optimally as a guide in the implementation of assessment of student attitudes during learning, due to a large number of administrations and things that are more concerned with, namely the learning process itself rather than looking at the journal.

\subsection{Engklek Game Rules}

In the game, engklek has several rules. Rules must be obeyed for the smooth running of the game. The rules and character education values contained in the engklek game regulations include: engklek game must be obeyed because with the rules children will not do their way and try to comply with the existing rules, so that children can learn to become sporty children to take action. The character education values contained in the rules of the engklek game include Honest, disciplined, responsible, hard work, Independent, disciplined, love homeland.

\subsection{The Value Character education In Mathematics learning by using the engklek game}

The second grade of MIN 9 Sragen integrates character education in mathematics learning. Mathematics is a process to obtain the essence of the human mind which is used as a means of managing problems. The values contained in mathematics learning include practical values and uses, disciplinary values, culture, morals, aesthetics, and recreational values [19]. second grade flat geometry material using learning media engklek game. Traditional games of engkleks can be used to learn the concept of the area of a square, rectangular, and trapezoidal shape [20]. The second grade mathematics material is explaining and classifying flat shapes and space shapes based on their characteristics [21]. In this study, learning mathematics material on the geometry of flat shapes only includes explaining and classifying flat shapes based on their characteristics. The media used is geometric engklek

Table 2. The value of character education contained in the rules of the engklek game

\begin{tabular}{|c|c|c|}
\hline No & Rules in playing engklek & Value of Character Education \\
\hline 1 & $\begin{array}{l}\text { When doing kicks, the player's feet must not hit the line or } \\
\text { step on the opponent's chop }\end{array}$ & $\begin{array}{l}\text { Honest, disciplined, responsible, hard work, love } \\
\text { homeland. }\end{array}$ \\
\hline 2 & $\begin{array}{l}\text { Gacuk Not allowed if it hits the line, if it hits the line it is } \\
\text { considered dead }\end{array}$ & $\begin{array}{l}\text { Honest, disciplined, responsible, hard work, love } \\
\text { homeland. } \\
\text { Can respect different opinions and actions of friends }\end{array}$ \\
\hline 3 & $\begin{array}{l}\text { Gacuk it must not be broken when thrown on the intended } \\
\text { plot if it is considered dead }\end{array}$ & Honest, disciplined, responsible, work hard \\
\hline 4 & $\begin{array}{l}\text { When doing teplek, if the mackerel falls from your hand then } \\
\text { you have to do it again when it is his turn }\end{array}$ & Honest, disciplined, responsible, hard work \\
\hline 5 & $\begin{array}{l}\text { Rice fields that do not belong to him may not be used } \\
\text { forelegs so that other players when passing through their } \\
\text { opponent's fields must be jumped over }\end{array}$ & Independent, responsible, disciplined \\
\hline 6 & $\begin{array}{l}\text { The player may hold on firmly to support his body while } \\
\text { bending down to pick up the mace. }\end{array}$ & Discipline, hard work \\
\hline
\end{tabular}

Based on the table above, shows that by complying with the rules in the engklek game, you can instill character education in each of the rules. The rules in the media. Geometry Engklek media. This Geometry Engklek media is a modification of the traditional game of engklek in general but does not change the 
characteristics of the traditional game of engklek. The field of play, gacuk game, and game rules in Engklek Geometry still refer to the traditional game of engklek. [22]. Before learning begins, students are divided into several small groups to facilitate the learning process by using the engklek game. The main purpose of applying the cooperative learning model is that students can learn together, allowing other people to exchange opinions.
By applying the cooperative model, it is hoped that it can train students to have thinking and social skills.. [23].

This is supported by the results of research conducted by the. The following are the steps for learning mathematics using the geometry material engklek game in the second grade of MIN 9 Sragen:

Table 3. Steps of learning mathematics using the crank game

\begin{tabular}{|c|c|c|}
\hline No & Learning Activities & $\begin{array}{l}\text { Value of character } \\
\text { education }\end{array}$ \\
\hline 1 & Students give greetings and pray according to their respective religions and beliefs & Religious \\
\hline 2 & $\begin{array}{l}\text { Students are given an explanation of the sides, angles, and angles of the flat shapes in the } \\
\text { engklek game) }\end{array}$ & Communication \\
\hline 3 & $\begin{array}{l}\text { The teacher explains and provides an explanation of the rules in the geometry engklek } \\
\text { game and provides examples of how to play it. }\end{array}$ & Communication \\
\hline \multirow[t]{6}{*}{4} & $\begin{array}{l}\text { Students play geometry engkleks according to applicable rules. As for the rules and how to } \\
\text { play engkleks are as follows: }\end{array}$ & $\begin{array}{l}\text { Discipline, } \\
\text { responsibility, love } \\
\text { homeland, }\end{array}$ \\
\hline & $\begin{array}{l}\text { Players hold hom-pim-pah if more than } 2 \text { people are playing, while there are } 2 \text { children to } \\
\text { draw the players }\end{array}$ & Honest, love homeland \\
\hline & $\begin{array}{l}\text { The player begins to play by throwing the hump onto grid one. Then the player engklek } \\
\text { (jumps) from the direct stage to the stage } 2,3,4,5,6 \text { and does brog (both feet stomping on } \\
\text { the ground) de the seventh plot }\end{array}$ & $\begin{array}{l}\text { Independent, honest, } \\
\text { love homeland }\end{array}$ \\
\hline & Return to the stage past 3,2 grid with engklek again & $\begin{array}{l}\text { Hard work, discipline, } \\
\text { responsibility, love } \\
\text { homeland }\end{array}$ \\
\hline & $\begin{array}{l}\text { When they reach square } 2 \text {, the player has to bend down and pick up the hump that is on } \\
\text { grid } 1 \text {, then return to the stage }\end{array}$ & $\begin{array}{l}\text { Hard work, discipline, } \\
\text { responsibility, love } \\
\text { homeland }\end{array}$ \\
\hline & $\begin{array}{l}\text { The player can get a paddy field if the player can cross all the tiles by throwing his huffs one } \\
\text { by one into squares 2,3,4.5.6 and } 7 \text {. If the mackerel reaches grid } 1 \text { again then the player } \\
\text { must do teplek (flip the hand and hump not may fall when doing teplek) }\end{array}$ & $\begin{array}{l}\text { Hard work, discipline, } \\
\text { responsibility, love } \\
\text { homeland }\end{array}$ \\
\hline 5 & $\begin{array}{l}\text { Before the students get to the rice fields, the students must answer the questions on the } \\
\text { boxes that are hit with the mumps }\end{array}$ & $\begin{array}{l}\text { Creativity, } \\
\text { Independent, To be } \\
\text { responsible }\end{array}$ \\
\hline
\end{tabular}




\begin{tabular}{lll} 
No & \multicolumn{1}{c}{ Rules in playing engklek } & \multicolumn{1}{c}{$\begin{array}{c}\text { Value of Character } \\
\text { Education }\end{array}$} \\
\hline $\begin{array}{l}\text { Students are invited to identify images and features of flat shapes in the geometric } \\
\text { engklek game }\end{array}$ & Creativity \\
\hline 7 & $\begin{array}{l}\text { Students are invited to calculate the many sides, angles, and angles of various shapes of } \\
\text { shapes. }\end{array}$ & Creativity \\
\hline 8 & $\begin{array}{l}\text { Students do the exercises through worksheets about the many sides, angles, and angles } \\
\text { of shapes filled in the tables in the Student Book. (Independent) }\end{array}$ & Creativity, To be \\
\hline 9 & $\begin{array}{l}\text { The student and the teacher jointly correct the students' work about the many sides, } \\
\text { angles, and angles of the plane. }\end{array}$ & Democratic, Love \\
\hline 10 & $\begin{array}{l}\text { Students and teachers ask and answer questions about material that is suitable for } \\
\text { learning }\end{array}$ & Communicative \\
\hline 11 & Students make conclusions in learning & Communicative \\
\hline 12 & Students pray according to their respective religions and beliefs
\end{tabular}

Based on the table above, it shows that in mathematics learning activities using the engklek game which includes praying, an explanation of the rules in the engklek game, identifying the characteristics and images of flat wakes, concluding lessons, working on worksheets, questions and answers between teachers and students about the subject matter taught. the teacher has to give provide opportunities for students to convey the results of their thinking openly, problems with students' understanding of mathematical objects will stimulate students to solve the problems they find [24]. In the learning activities above, it has been seen that the value of character education includes Religious, Communicative, discipline, responsibility, Honest, Independent, Hard work, discipline, responsibility, Tolerant, democratic, creative, Creativity, Love peace, tolerant, To be responsible, love homeland. In problemsolving, students are trained to explore ideas and construct knowledge independently without being too dependent on the teacher. Besides, each of the guided discovery-based learning stages present in the worksheet provides students with opportunities to develop students' mathematical creative thinking ability [25]. Critical thinking skills particularly doing math needs special attention in the learning process. In the learning process in class, the teacher has to instill solving problem skills and to think critically in mathematics by relating mathematics problems with daily life and cultural values in society [26].

Based on observations of learning activities using the engklek game, it appears that students are very happy and enthusiastic about participating in learning.
In the activity, students follow the rules in the game and can identify pictures and features of flat shapes.

Based on interviews with several second graders, they are very happy to learn difficult mathematics by playing engkleks because it is easier to understand the subject matter. Students are very happy to learn by playing so that learning is not boring.

Meanwhile, based on interviews with second-grade teachers said that learning mathematics which was considered difficult and scary turned into a fun and easy lesson to understand. Besides, students interact, communicate so that they can strengthen social relationships between them. Traditional games are activities that are entertaining in nature using simple tools and without tools that have been passed down from generation to generation. Traditional games provide good benefits for children's development, both physically, emotionally, and cognitively [27]. Character values believe that everything that is to come is related to the cultivation of education at this time [28].

Based on the results of teacher observations and assessments regarding the achievement of character education outcomes for Class II students in mathematics learning using the engklek game, it was found that out of 74 students 5 students got BT (Not Fulfilled) scores, 5 students got MT (Full Start), 45 students MB (Starting to Develop) and 19 students scored M (Cultivation). While the BT category BT (Unseen) If students have not shown the initial signs of behavior stated in the indicators because they do not understand the meaning of these values. MT (Starting to Look) If students have started to show early signs of behavior stated in the 
indicators but not consistent because there is already understanding and getting reinforcement from the immediate environment. MB (Start Developing) if students have shown various early signs of behavior that are stated in the indicators and begin to be consistent because besides there is already understanding and awareness getting reinforcement from the immediate environment and the wider environment.

After seeing the journal data on the value of character education in students by using the engklek game, it shows that playing engkleks has many advantages, among other things. Increase the physical abilities of each player, through jumping jumps, so that blood circulation can be improved, train body balance, because the engklek is only played by one leg, Sharpen one's social skills with others and provide a shared value when the game is played. Can try to obey the rules that have become an agreement between the players, Welcoming logical intelligence in the players, because in this game someone is also taught to practice arithmetic and the stages that must be passed, to be more creative, because traditional types of games are generally made directly by the players, using items around the environment, then processing them into a fun game. This is what makes them more creative in producing games [29]. By showing the many benefits of traditional games, This shows that the assumption of learning only in class is wrong because by playing students can also learn. Learning resources are not only obtained inside the class but also through the surrounding environment and the natural environment that makes students have the noble value of their region [30].

The importance of preserving is because Indonesian society is diverse in the culture, so preserving one's own culture is very important [31]. Traditional culture must be developed because the culture is one of the essential aspects of the school development program because it has ethical values for students [ 32]. If traditional culture is not developed it will result in the problem of nationalism can be seen from this time among Indonesian students who tend to start the culture of foreign countries. The influence of foreign cultures that are incompatible with Indonesian culture raises problems that affect student nationalism [33]. The use of ethnomathematics based teaching materials is proven to be effective on problem skills and mathematical critical thinking skills because the teaching materials are related to local culture and experiences of everyday life experienced by students[34]. The culture-based mathematics learning approach aims to connect the knowledge students already have with mathematics learning in schools [35]. Ethnomathematics-based teaching materials can make it easier for students to build their knowledge inductively even though students still experience obstacles in composing mathematical forms [36].

\section{CONCLUSION}

Based on the results of research and discussion, it shows that the value of character education in students can be instilled through learning activities using traditional engklek games as a means. In these learning activities, it can instill the value of character education which includes The results of this study are in the form of character education values contained in the game including religion, nationalism (love homeland, love peace), independence (Creativity Hard work, discipline), integrity (responsibility, honest), cooperation (tolerant, democratic communicative). This research can provide a real picture of the character education values of the younger generation who will become the nation's next generation. Judging from the responses of teachers, students, and school principals, It is seen that character education is instilled through various learning activities. However, the school still needs to instill the value of character education through learning activities by carrying out even better innovations. Besides, it is also necessary to develop activities outside the classroom/outside of learning.

\section{REFERENCES}

[1] C. F. Peng, H. Zulnaidi, \& F. Hutagalung, "The Intermediary Effect of Nationalism on the Relationship of Religion, Values, and Culture with Unity among Pre-Service Teachers in Malaysia,".J. Pertanika J. Soc. Sci. \& Hum, 27 (4): 2455 - 2473 , 2019.

[2] R. Yulita, "Permainan Tradisional Anak Nusantara. Jakarta:Badan Pengembangan dan Pembinaan Bahasa, 2017.

[3] N. Aneja, "The Importance of Value Education in the Present Education System \& Role of Teacher, " International Journal of Social Science and Humanities Research, ISSN 2348-3164 Vol. 2, Issue 3, pp: 230-233, 2014

[4] B. Yuniarto, "Developing Democratic Culture through Civic Education, " Pertanika J. Soc. Sci. \& Hum. 27 (2): 915 - 924, 2019.

[5] A. Rahman, "Values Education and the Malaysia Education Blueprint," Malaysia Journal of Interdisciplinary Research in Education (JIRE), ISSN 2232-0180, Vol. 4, Issue 1, pp. 59-73, 2014

[6] M. A. Pike, "Christianity and character education: faith in core values?,". J.of Beliefs \& Values: Studies in Religion \& Education, 31(3), 311-312, 2010

[7] G. Masadis, et al, "Traditional Dances as A Means of Teaching Social Skills to Elementary School Students," Int. J. Instr., vol. 12, no. 1, pp. 511-520, 2019 
[8] Peraturan Menteri Pendidikan Dan Kebudayaan Republik Indonesia Nomor 20 Tahun 2018 about Penguatan Pendidikan Karakter Pada Satuan Pendidikan Formal

[9] A. Rahman, "Values Education and the Malaysia Education," J. of Interdisciplinary Research in Education (JIRE), ISSN 2232-0180 Vol. 4, Issue 1, 2014, pp. 59-73, 2014

[10] Zamroni, Kultur sekolah [School culture], Yogyakarta: Indonesia : Gavin Kalam Utama, 2016

[11] Rahmatullah, A. Hasanah, U. Ruswandi." Character Education Of Food Local Culture Values In The People Of Kampung Adat Cirendeu In West Java Through Exemplary,". J.Pendidikan Karakter, No. 1,2020

[12] S. Patimah, "Teachers' Work Culture in an Islamic Junior High School inLampung, Indonesia,". Pertanika J. Soc. Sci. \& Hum. 27 (1): 123 - 132, 2019.

[13] S. Haryati, Tangkas Fisik-Motorik dengan Permainan Tradisional, Yogyakarta: Pustaka Belajar, 2018

[14] Tim Playplus Indonesia, Ensiklopedia Permainan Tradisional Anak Indonesia, Jakarta: Erlangga, 2017

[15] C. Febriyanti, R. Prasetya \& A. Irawan, "Etnomatematika Pada Permainan Tradisional Engklek Dan Gasing Khas Kebudayaan Sunda,"J. Ilmu Matematika dan Terapan, Volume 12 Nomor 1 | pp. 1 - 6 DOI: 10.30598/vol12iss 1pp1-6ar358, 2018.

[16] K. T. Mahardewi, \& M. Magta, "Penerapan permainan tradisional engklek untuk meningkatkan kemampuan motorik kasar kelompok B di PAUD WIDHYA LAKSMI Singaraja Tahun Ajaran 2015/2016," J.Pendidikan Anak Usia Dini Undiksha, 4(3), 2016.

[17] M. B. Milles and A. M. Huberman, "Analisis Data Kualitatif," Jakarta: Universitas Indonesia Press, 1992 .

[18] A. S. Abdullah, " Ethnomathematics In Perspective Of Sundanese Culture,".Journal on Mathematics Education Vol. 8, No. 1, pp. 1-16 ISSN 2087-8885 E-ISSN 2407-0610, 2017.

[19] A. D. Damayanti, \& R. Putranti, "Pembelajaran Matematika dalam Permainan Tradisional Engklek Untuk Siswa SD Kelas V,"Prosiding Seminar Nasional Matematika dan Terapannya, Universitas Jenderal Soedirman, 253-260, 2016.
[20] Peraturan Menteri Pendidikan Dan Kebudayaan Republik Indonesia Nomor 37 Tahun 2018 about Perubahan Atas Peraturan Menteri Pendidikan Dan Kebudayaan Nomor 24 Tahun 2016 Tentang Kompetensi Inti Dan Kompetensi Dasar Pelajaran Pada Kurikulum 2013 Pada Pendidikan Dasar Dan Pendidikan Menengah .

[21] I. Nur et al,"Engklek Geometri: Upaya Pelestarian Permainan Tradisional Melalui Proses Pembelajaran Matematika Di Smp Muhammadiyah 4 Surabaya, " J-ADIMAS (Jurnal Pengabdian kepada Masyarakat). Vol. 6 Nomor 1: 12 - 18, 2017 .

[22] N. Siregar \& W. Lestari, "Peranan Permainan Tradisional Dalam Mengembangkan Kemampuan Matematika Anak Usia Sekolah Dasar"J.Mercumatika, Vol. 2 No 2, hlm. 1-7 ISSN: 2548-1819, Maret. 2018.

[23] A. Afandi, "Difference Of Learning Mathematics Between Open Question Model And Conventional Model, "Malikussaleh Journal of Mathematics Learning (MJML), 1(1), 13-18, 2018.

[24] Usmadi \& Ergusni, "Design of ARCSI Learning Model with Scientific Approach for Teaching Mathematics in School, "International Journal of Trends in Mathematics Education Research, 1(1), 13-18. doi:10.33122/ijtmer.v1i1.28, 2018 .

[25] T. Yuliani, S. H. Noer, and U. Rosidin, "Guided Discovery Worksheet for Increasing Mathematical Creative Thinking and Self-Efficacy, "International Journal of Trends in Mathematics Education Research, Vol. 1, No. 1, pp. 30-34, 2018.

[26] O. A. Cimen, "Discussing Ethnomathematics: Is Mathematics Culturally Dependent?," Procedia Social and Behavioral Sciences, 152, 523-528. doi:10.1016/j.sbspro.2014.09.215, 2014.

[27] A. Agboola \& K. C. Tsai, "Bring Character Education into Classroom. European Journal of Educational Research, " 1(1), pp. 163-170, 2012.

[28] C. C. Febriyanti, R. Prasetya \& A. Irawan,"Etnomatematika Pada Permainan Tradisional Engklek Dan Gasing Khas Kebudayaan Sunda,"J.Ilmu Matematika dan Terapan, Vol. 12 \begin{tabular}{l|llll} 
Nomor 1 & Hal. $1-6$ & -6
\end{tabular} 10.30598/vol12iss1pp1-6ar358 , 2018. .

[29] Anwar, B. Wibawa, and N. Ibrahim, "Development of Teaching Materials for Sasak Alus Language as Cultural Preservation and Learning Resources, "Humanit. Soc. Sci. Rev., vol. 7, no. 5, pp. 556$563,2019$. 
[30] A. M. Ali Imron and F. Nugrahani, "Strengthening Pluralism in Literature Learning for Character Education of School Students,".j.Humanit. Soc. Sci. Rev., vol. 7, no. 3, pp. 207-213, 2019.

[31] S. P. Daniati, S. Subiyantoro, and S. S. Fadhilah, "Natural School Culture as A Free and Fun Alternative Education in Building the Students Character, "Elem Educ. Online2, vol. 18, no. 1, pp. 331-342, 2019.

[32] N. Temiz, "Analysis of 1st Grade Social Studies Curriculum of 2018 in Terms of Character Education, "İlköğretim Online, vol. 19, no. 4, pp. 2370-2381, 2020 .

[33] M. D. Niron, C. A. Budiningsih, and Pujiriyanto, "Rujukan Integratif Dalam Pelaksanaan Pendidikan Karakter Di Sekolah Dasar,"J. Kependidikan, vol. 43, no. 1, pp. 19-31, 2018.
[34] W. V. Alangui, "Ethnomathematics and Culturally Relevant Mathematics Education in the Philippines. Ethnomathematics and Its Diverse Approaches for Mathematics Education, "183-208. doi:10.1007/978-3-319-59220-6_8, 2017 .

[35] Arisetyawan, "Study of Ethnomathematics: A lesson from the Baduy Culture, International," Journal of Education and Research, Vol.2 No.10. pp .681-688, 2014.

[36] Dahlan, A. Jarnawi and R. Permasari,"Pengembangan Bahan Ajar Berbasis Etnomatematika dalam Pembelajaran Matematika Sekolah Menengah Pertama,," JNPM (Jurnal Nasional Pendidikan Matematika, Vol 2(1) hal 133-150, 2018 